\title{
THE EFFECT OF READING COMPREHENSION ABILITY TO MATHEMATICAL PROBLEM SOLVING ABILITY FOR FIFTH GRADE STUDENTS OF PUBLIC ELEMENTARY SCHOOLS IN KEBUMEN SUB-DISTRICT IN ACADEMIC YEAR OF 2019/2020
}

\author{
Frida Noor Afifah ${ }^{1}$, Joharman $^{2}$, Rokhmaniyah ${ }^{3}$ \\ Sebelas Maret University \\ e-mail: fridaafifah07@gmail.com
}

\section{Article History \\ accepted 01/06/2020}

approved 01/07/2020 published 01/08/2020

\begin{abstract}
The study aimed to prove significant and positive correlation between reading comprehension ability and mathematical problem solving ability and to determine the contribution of reading comprehension ability to mathematical problem solving ability for fifth grade students of public elementary schools in Kebumen sub-district in academic year 2019/2020. The research was a quantitative research with correlation method. The prerequisite test analysis used normality and linearity. Data analysis included simple correlation test and adjusted $R$ square. The result indicates that there is positive and significant correlation between reading comprehension ability and mathematical problem solving ability. The correlation level is moderate which is 0.587 and the contribution of reading comprehension ability to mathematical problem solving ability is $25.8 \%$. It concludes that there is positive and significant correlation between reading comprehension ability and mathematical problem solving ability for fifth grade students of public elementary schools in Kebumen sub-district in academic year of 2019/2020.
\end{abstract}

Keywords: Reading Comprehension, Problem Solving, Mathematics

\begin{abstract}
Abstrak
Penelitian ini bertujuan untuk mengetahui adanya korelasi positif yang signifikan antara kemampuan membaca pemahaman dengan kemampuan pemecahan masalah matematika dan menghitung besarnya sumbangan kemampuan membaca pemahaman terhadap kemampuan pemecahan masalah matematika siswa kelas V SDN se-Kecamatan Kebumen tahun ajaran 2019/2020. Penelitian ini merupakan penelitian kuantitatif dengan metode korelasi. Uji prasyarat meggunakan uji normalitas dan linieritas. Analisis data dalam penelitian ini yaitu uji korelasi sederhana dan sumbangan efektif (SE). Penelitian ini menghasilkan kesimpulan bahwa terdapat korelasi positif yang signifikan antara kemampuan membaca pemahaman dan kemampuan pemecahan masalah matematika dengan tingkat korelasi sedang yaitu 0,587 dan sumbangan variabel kemampuan membaca pemahaman terhadap kemampuan pemecahan masalah matematika yaitu 25,8\%. Berdasarkan hasil penelitian tersebut dapat disimpulkan bahwa terdapat korelasi positif yang signifikan antara kemampuan membaca pemahaman dan kemampuan pemecahan masalah matematika siswa kelas V SD Negeri se-Kecamatan Kebumen tahun ajaran 2019/2020.
\end{abstract}

Kata kunci: Membaca Pemahaman, Pemecahan Masalah, Matematika 


\section{PENDAHULUAN}

Matematika merupakan salah satu bidang studi yang dipelajari pada seluruh jenjang pendidikan, dari tingkat sekolah dasar hingga pendidikan tinggi. Menurut Wahyudi (2015: 68), matematika adalah bahan kajian yang berkonsep abstrak dan dibangun melalui proses penalaran deduktif, dimana kebenaran suatu konsep diperoleh sebagai akibat dari kebenaran sebelumnya yang sudah diterima sehingga kebenaran antar konsep dalam matematika bersifat kuat dan jelas.

Cooney berpendapat bahwa sebuah pertanyaan matematika akan menjadi masalah jika pertanyaan itu menunjukkan adanya suatu tantangan yang tidak dapat dipecahkan oleh prosedur rutin yang sudah diketahui siswa (Roebyanto \& Harmini, 2017: 2). Hal ini sejalan dengan pendapat Nurwiyana (2018: 3) yang menyatakan bahwa masalah dalam matematika yaitu ketika seseorang dihadapkan pada persoalan matematika tetapi tidak bisa mendapatkan solusinya secara langsung.

Pemecahan masalah merupakan suatu cara yang dimiliki setiap orang untuk mengatasi masalah yang sedang dihadapi. Dalam pembelajaran matematika di sekolah lebih dikenal dengan pemecahan masalah matematika. Hal utama dalam memecahkan masalah matematika adalah pemahaman terhadap masalah yang terdapat dalam teks bacaan. Permasalahan matematika dapat diselesaikan dengan perencanaan yang matang dan langkah-langkah yang runtut seperti yang dijelaskan oleh Polya (Roebyanto \& Harmini, 2017: 34) langkah-langkah menyelesaikan masalah matematika terdiri dari 4 tahap, yaitu: (1) memahami masalah; (2) merencanakan penyelesaian; (3) menyelesaikan masalah sesuai rencana; (4) melakukan pengecekan kembali terhadap semua langkah yang dikerjakan. Dalam menyelesaikan masalah matematika, siswa harus mengonversikan tulisan ke dalam bentuk angka. Pengonversian kalimat cerita menjadi angka memerlukan kemampuan membaca pemahaman. Hal ini sejalan dengan pendapat Phonapichat, Wongwanich, \& Sujiva (2014: 3170) yang artinya, untuk memecahkan masalah matematika, siswa memerlukan keterampilan membaca, terutama pemahaman membaca dan analisis teks. Pendapat serupa disampaikan oleh Auzar (2013: 34) yang menyatakan bahwa keterampilan membaca pemahaman dan pemahaman konsep hitung matematika saling berhubungan dan sangat diperlukan untuk memahami dan menyelesaikan permasalahan matematika.

Kemampuan membaca pemahaman yang dimiliki oleh seseorang merupakan hasil dari proses belajar mengajar yang dilakukan dengan tekun dan terlatih. Menurut Laily (2014: 53), membaca pemahaman adalah kemampuan seseorang dalam memahami isi bacaan dan dibatasi pada pertanyaan apa, bagaimana, mengapa, dimana, dan kesimpulan berdasarkan masalah dan isi bacaan. Hal ini sejalan dengan pendapat Maruti (Rudyanto, 2017: 45), membaca pemahaman adalah suatu kegiatan membaca yang tujuan utamanya yaitu memahami isi bacaan secara tepat dan cepat. Jika kemampuan membaca pemahaman tidak dikuasai dengan baik, maka siswa tidak akan memperoleh tingkat pemahaman yang baik.

Menurut Hafner dan Jolly (Pramila Ahuja dalam Faizun, 2015: 14), pemahaman terhadap teks bacaan dapat diketahui ketika siswa mampu melakukan hal-hal berikut: (1) menjawab pertanyaan sesuai isi bacaan; (2) menentukan ide pokok paragraf; (3) menentukan kalimat utaman suatu paragraf; dan (4) menyebutkan contoh penerapan isi bacaan dalam kehidupan sehari-hari.

Berdasarkan uraian di atas, penting kiranya dilakukan penelitian untuk mengetahui ada tidaknya hubungan antara kemampuan membaca pemahaman dengan kemampuan pemecahan masalah matematika dan menghitung besarnya sumbangan kemampuan membaca pemahaman terhadap kemampuan pemecahan masalah matematika yang dimiliki siswa kelas V SD di Kecamatan Kebumen melalui penelitian kuantitatif dengan judul "Pengaruh Kemampuan Membaca Pemahaman 
terhadap Kemampuan Pemecahan Masalah Matemarika Siswa Kelas V SD Negeri seKecamatan kebumen Tahun Ajaran 2019/2020".

Tujuan penelitian ini adalah: (1) mengetahui ada tidaknya hubungan antara kemampuan membaca pemahaman dengan kemampuan pemecahan masalah matematika siswa kelas V SDN se-Kecamatan Kebumen tahun ajaran 2019/2020; (2) menghitung besarnya sumbangan kemampuan membaca pemahaman siswa terhadap kemampuan pemecahan masalah matematika siswa kelas V SDN se-Kecamatan Kebumen tahun ajaran 2019/2020.

\section{METODE}

Penelitian ini merupakan penelitian kuantitatif dengan metode korelasi. Populasi penelitian ini adalah seluruh siswa kelas $\mathrm{V}$ di 59 SDN se-kecamatan Kebumen tahun ajaran 2019/2020 yang berjumlah 1.598 siswa. Sampel pada penelitian ini berjumlah 335 siswa kelas $\mathrm{V}$ di dua belas SDN se-Kecamatan Kebumen yang dipilih secara acak dengan teknik cluster random sampling. Pengambilan sampel dengan cara cluster random sampling adalah melakukan randomisasi terhadap kelompok (sekolah), bukan terhadap subjek secara individual. Sekolah yang digunakan pada penelitian ini yaitu SDN 2 Kebumen, SDN 5 Kebumen, SDN 2 Panjer, SDN 1 Kutosari, SDN 5 Bumirejo, SDN 3 Selang, SDN 2 Tamanwinangun, SDN 3 Tamanwinangun, SDN 2 Depokrejo, SDN 1 Kalibagor, SDN 1 Tanahsari, dan SDN 1 Kalirejo.

Teknik pengumpulan data pada penelitian ini menggunakan tes. Teknik tes digunakan untuk mengumpulkan data kemampuan membaca pemahaman dan kemampuan pemecahan masalah matematika. Uji prasyarat analisis data yang digunakan yaitu uji normalitas dan uji linieritas. Analisis data yang digunakan yaitu uji korelasi sederhana dan sumbangan efektif (SE) dengan taraf signifikansi $5 \%$.

\section{HASIL DAN PEMBAHASAN}

Penelitian ini dilakukan dengan memberikan tes kemampuan membaca pemahaman dan tes kemampuan pemecahan masalah matematika kepada siswa di dua belas SDN di Kecamatan Kebumen. Tes ini berisi soal-soal yang memuat indiakator kemampuan membaca pemahaman dan kemampuan pemecahan masalah matematika sehingga dapat mengukur tinggi rendahnya kemampuan membaca pemahaman dan kemampuan pemecahan masalah matematika. Prasyarat data terpenuhi yaitu data berasal dari populasi berdistribusi normal dan terdapat hubungan linear antara kemampuan membaca pemahaman dan kemampuan pemecahan masalah matematika. Data hasil penelitian berasal dari data berdistribusi normal yang ditunjukkan dengan nilai signifikansi kemampuan membaca pemahaman 0,053 dan kemampuan pemecahan masalah matematika 0,200. Kedua nilai signifikansi data menunjukkan nilai $>0,05$ sehingga data tersebut berasal dari populasi berdistribusi normal. Data dikatakan terdapat hubungan linear antara variabel $X$ dan $Y$ jika $p$ value Deviation from Linearity $>0,05$. Nilai $p$ value Deviation from Linearity yaitu $0,105>0,05$ sehingga terdapat hubungan linear antara kemampuan membaca pemahaman dan kemampuan pemecahan masalah matematika.

Korelasi antara kemampuan membaca pemahaman dan kemampuan pemecahan masalah matematika diuji menggunakan uji korelasi pearson product moment. Uji Korelasi menggunakan bantuan aplikasi SPSS versi 25.

Hipotesis yang digunakan adalah $\mathrm{H}_{0}=$ tidak ada hubungan antara kemampuan membaca pemahaman dan kemampuan pemecahan masalah matematika dan $\mathrm{H}_{1}=$ ada hubungan antara kemampuan membaca pemahaman dan kemampuan pemecahan masalah matematika. 
Tabel 1 Hasil Analisis Korelasi Kemampuan Membaca Pemahaman dengan Kemampuan Pemecahan Masalah Matematika

Correlations

\begin{tabular}{llr|r} 
& & \multicolumn{1}{c|}{$\begin{array}{c}\text { Membaca } \\
\text { Pemahaman }\end{array}$} & \multicolumn{2}{c}{$\begin{array}{c}\text { Memecahan } \\
\text { Masalah } \\
\text { Matematika }\end{array}$} \\
\hline $\begin{array}{l}\text { Membaca } \\
\text { Pemahaman }\end{array}$ & Pearson Correlation & 1 &, $587^{* *}$ \\
\cline { 2 - 4 } Sig. (1-tailed) & $\mathrm{N}$ & 335 &, 000 \\
\hline Pemecahan & Pearson Correlation &, $587^{* *}$ & 335 \\
Masalah & Sig. (1-tailed) &, 000 & 1 \\
Matematika & $\mathrm{N}$ & 335 & 335 \\
\hline
\end{tabular}

**. Correlation is significant at the 0.01 level (1-tailed).

Berdasarkan analisis data menggunakan uji korelasi pearson product moment, diketahui bahwa terdapat hubungan positif yang signifikan antara kemampuan membaca pemahaman dengan kemampuan pemecahan masalah matematika siswa kelas $\mathrm{V}$ dengan koefisien korelasi sebesar 0,587 dan Sig. (1-tailed) yaitu 0,000 ( $p$ value $<0,05$ ). Nilai 0,05 adalah taraf signifikansi yang digunakan pada penelitian ini. Sesuai dengan hasil uji korelasi tersebut, maka hipotesis yang menyatakan bahwa terdapat terdapat hubungan yang positif dan signifikan antara kemampuan membaca pemahaman dan kemampuan pemecahan masalah matematika siswa kelas V SDN se-Kecamatan Kebumen tahun ajaran 2019/2020 dapat diterima. Hasil analisis koefisien korelasi antara variabel kemampuan membaca pemahaman dan kemampuan pemecahan masalah matematika yaitu 0,587. Berdasarkan pendapat Sugiyono (2015: 231) mengenai pedoman interpretasi terhadap koefisien korelasi menyatakan bahwa koefisien korelasi pada penelitian ini yaitu 0,587 berada pada tingkat hubungan sedang.

Sesuai hasil perhitungan sumbangan kemampuan membaca pemahaman terhadap kemampuan pemecahan masalah matematika sebesar $25,8 \%$ dan sisanya sebesar $74,2 \%$ dipengaruhi oleh faktor lain. Hal ini sesuai dengan penelitian yang dilakukan oleh Calistra, Imam, dan Winarni (2016: 289) yang menyatakan bahwa kemampuan membaca pemahaman bukan satu-satunya faktor yang menyebabkan meningkatnya kemampuan pemecahan masalah matematika siswa, tetapi terdapat faktor lain yang mempengaruhi tinggi rendahnya kemampuan pemecahan masalah matematika siswa.

Berdasarkan penelitian dan perhitungan yang telah dilakukan, dapat diketahui bahwa kemampuan membaca pemahaman memiliki hubungan yang positif dengan kemampuan pemecahan masalah matematika. Oleh karena itu, dapat dikatakan bahwa semakin tinggi kemampuan membaca pemahaman siswa maka semakin tinggi pula kemampuan pemecahan masalah matematika siswa. Begitu juga sebaliknya, semakin rendah kemampuan membaca pemahaman siswa maka akan semakin rendah pula kemampuan pemecahan masalah matematika siswa.

Hasil penelitian ini sesuai dengan penelitian yang dilakukan oleh Calista, Imam, dan Winarni (2016: 289) yang menyatakan bahwa terdapat hubungan yang positif dan signifikan antara kemampuan membaca pemahaman dengan kemampuan pemecahan masalah matematika dengan nilai korelasi product moment sebesar 0,721 . Perbedaan penelitian yang dilakukan oleh Calista, Imam dan Winarni dengan penelitian yang dilakukan oleh peneliti terletak pada kelas yang diteliti. Pada penelitian Calista, Imam 
dan Winarni dilakukan di kelas IV SD, sedangkan penelitian ini dilakukan di kelas V SD. Penelitian lain yang dilakukan pada siswa kelas V SD Muhammadiyah Ambarbinangun juga mengungkapkan bahwa keterampilan membaca pemahaman berhubungan positif terhadap kemampuan memecahkan masalah matematika siswa dengan nilai korelasi product moment sebesar 0,746 (Andanik dan Fitrianawati, 2018: 45-46). Sedangkan penelitian yang dilakukan oleh Andanik dan Fitrianawati dengan penelitian yang dilakukan oleh peneliti adalah pada jumlah subjek penelitian, penelitian Andanik dan Fitrianawati hanya dilakukan di 1 SD, sementara penelitian ini dilakukan di 1 Kecamatan.

Hasil perhitungan sumbangan efektif pada variabel kemampuan membaca pemahaman dan kemampuan pemecahan masalah matematika didapatkan hasil sebesar $25,8 \%$, artinya kemampuan membaca pemahaman yang dimiliki siswa dapat berperan dalam meningkatkan kemampuan pemecahan masalah matematika sebesar $25,8 \%$ dna sisanya sebesar $74,2 \%$ dipengaruhi oleh faktor lain seperti kesehatan, motivasi, kemandirian, sarana dan prasarana.

\section{SIMPULAN}

Berdasarkan hasil penelitian dan pembahasan yang telah diuraikan, maka dapat disimpulkan bahwa: (1) kemampuan membaca pemahaman memiliki hubungan yang positif dan signifikan dengan kemampuan pemecahan masalah matematika siswa kelas V SD Negeri se-Kecamatan Kebumen dengan tingkat korelasi sedang yaitu 0,587 ; (2) besar sumbangan variabel kemampuan membaca pemahaman terhadap kemampuan pemecahan masalah matematika yaitu $25,8 \%$.

Berdasarkan simpulan yang telah dipaparkan, peneliti memberikan beberapa saran: (1) bagi guru, selalu memotivasi siswa untuk meningkatkan kemampuan membaca pemahamannya dengan memberikan latihan berupa teks bacaan yang menarik serta membiasakan siswa untuk membaca berulang-ulang untuk memahami maksud kalimat di dalam teks bacaan; (2) bagi sekolah, pihak sekolah sebaiknya melengkapi referensi buku bacaan di perpustakaan agar siswa semakin tertarik untuk membaca sehingga dapat meningkatkan kemampuan membaca pemahaman siswa; (3) bagi peneliti selanjutnya dapan melakukan penelitian terkait dengan faktor lain yang memengaruhi kemampuan pemecahan masalah matematika siswa dan penelitian ini dapat menjadi acuan dalam penelitian korelasi dan diharapkan mencari sumber referensi lainnya agar hasil penelitiannya akan jauh lebih baik.

\section{DAFTAR PUSTAKA}

Andanik, R.T. \& Fitrianawati, M. (2018). Pengaruh Keterampilan Membaca Pemahaman terhadap Kemampuan Pemecahan Soal Cerita Matematika Peserta Didik Kelas V Sekolah Dasar. Fundamental Pendidikan Dasar, 2(2), 40-46.

Auzar. (2013). Hubungan Kemampuan Membaca Pemahaman dengan Kemampuan Memahami Bahasa Soal Hitungan Cerita Matematika Muris-murid Kelas V SD 006 Pekanbaru. Jurnal Bahas, 8(1), 33-38.

Calista, K., Imam, S., \& Winarni, E.S. (2016). Hubungan antara Kemampuan Membaca Pemahaman dengan Penyelesaian Masalah Matematika Siswa Kelas IV di SDN se-Kabupaten Malang. Dalam Muchtar, Heru, Sumanto, \& Harti (Ed.). Prosiding Seminar Nasional Konstelasi Pendidikan dan Kebudayaan Indonesia di Era Globalisasi, hlm. 283-290. Malang: Universitas Negeri Malang.

Faizun, N.R. (2015). Hubungan antara Membaca Pemahaman dengan Kemampuan Menyelesaikan Soal Cerita Matematika pada Siswa Kelas IV SD se-Gugus Karangmojo III Gunung Kidul. Kumpulan Abstrak Hasil Penelitian Universitas negeri Yogyakarta, HIm. 14-64. LPPM UNY.

Laily, I.A. (2014). Hubungan Kemampuan Membaca Pemahaman dengan Kemampuan memahami Soal Cerita Matematika Sekolah Dasar. EduMa, 3(1), 52-62. 
Nurwiyana, L. (2018). Analisis Kesalahan Siswa dalam Menyelesaikan Masalah Matematika berdasarrkan Langkah Polya Ditinjau dari Minat Belajar. Skripsi Tidak Dipublikasikan, Universitas Muhammadiyah Ponorogo, Ponorogo.

Phnopichat, P., Wongwanich, S., \& Sujiva, S. (2014). An Analysis of Elementary School Students' Difficulties in Mathematical Problem Solving. Procedia Social and Behavioral Sciences, 116, 3169-3174.

Roebyanto, G \& Harmini, S. (2017). Pemecahan Masalah Matematika untuk PGSD. Bandung: PT Remaja Rosdakarya.

Rudyanto, H.E. (2017). Pengaruh Kemampuan Membaca Pemahaman terhadap Prestasi Belajar Matematika pada Pokok Bahasan Soal Cerita Kelas IV. Jurnal Kependidikan Dasar Islam Berbasis Sains, 2(2), 43-50.

Sugiyono. (2015). Metode Penelitian Pendidikan: Pendekatan Kuantitatif, Kualitatif, dan $R \& D$. Bandung: Alfabeta.

Wahyudi (2015). Panduan Pembelajaran Matematika di Sekolah Dasar (Untuk Guru dan Calon Guru). Surakarta: UNS Press. 